\title{
Synapse Formation and Establishment of Neuronal Polarity by P19 Embryonic Carcinoma Cells and Embryonic Stem Cells
}

\author{
Michael F. A. Finley, Nita Kulkarni, and James E. Huettner \\ Department of Cell Biology and Physiology and Program in Neuroscience, Washington University Medical School, \\ St. Louis, Missouri 63110
}

\begin{abstract}
A number of different cell lines that exhibit a partial neuronal phenotype have been identified, but in many cases the full extent of their neuronal differentiation has not been directly addressed by functional studies. We have used electrophysiology and immunofluorescence to examine the formation of synapses and the development of neuronal polarity by murine embryonic stem (ES) cells and the mouse P19 embryonic carcinoma cell line. Within 2-3 weeks after induction by retinoic acid, subsets of P19 and ES cells formed excitatory synapses, mediated by glutamate receptors, or inhibitory synapses, mediated by receptors for GABA or glycine. In ES-cell cultures, both NMDA and non-NMDA receptors contributed to the excitatory postsynaptic response. Staining with antibodies to
\end{abstract}

growth-associated protein-43 and microtubule-associated protein-2 revealed segregation of immunoreactivity into separate axonal and somato-dendritic compartments, respectively. Consistent with our physiological evidence for synapse formation, intense punctate staining was observed with antibodies to the synaptic vesicle proteins synapsin, SV2, and synaptophy$\sin$. These results demonstrate the in vitro acquisition by pluripotent cell lines of neuronal polarity and functional synaptic transmission that is characteristic of CNS neurons.

Key words: embryonic stem cells; embryonic carcinoma cells; neuronal differentiation; synaptic transmission; neuronal polarity; NMDA receptors
Because CNS neurons differentiate in a complex environment that is largely inaccessible to experimental manipulation, relatively little is known about the intrinsic and extrinsic factors that determine their ultimate phenotype. To address this question, a number of systems that undergo all or part of the differentiation process in vitro have been explored. Several groups have isolated neuronal precursors from embryonic brain or have produccd immortalized cell lines by introducing oncogenes into dividing cells from the early CNS (for review, see Gage et al., 1995). A separate line of research has focused on the induction of neuronal differentiation in pluripotent cells derived from very early embryos. Acquisition of neuronal properties has been demonstrated for embryonic carcinoma cells, including mouse P19 cells (JonesVilleneuve et al., 1982; McBurney et al., 1988) and human NTera-2 cells (Andrews, 1984; Pleasure et al., 1992) and, more recently, for embryonic stem cells (Bain et al., 1995), the totipotent cells that are used to generate transgenic mice (Capecchi, 1989).

For any cell type that differentiates in vitro, it is important to ask how far the cells progress along a given developmental pathway and how closely their final differentiated state corresponds to that

Received Sept. 6, 1995; revised Nov. 8, 1995; accepted Nov. 10, 1995.

This work was supported by a National Science Foundation Graduate Fellowship (M.F.A.F.), a Howard Hughes Undergraduate Research Fellowship (N.K.), National Institutes of Health Grant NS30888 (J.E.II.), and the McDonnell Center for Cellular and Molecular Neurobiology. We are grateful to Dave Gottlieb for advice and encouragement throughout the course of this study. We also thank the following individuals for providing research materials: Kathy Buckley, Dave Gottlieb, David James, Bob Wilkinson, and Mark Willard. We are also grateful to Audrey Ettinger, Chris Lee, Tim Wilding, and Dave Gottlieb for critical reading of this manuscript, to Steve Mennerick for advice on setting up microisland cultures, and to Min Yao for help with ES-cell induction procedures.

Correspondence should be addressed to Dr. James E. Huettner, Washington University Mcdical School, Department of Cell Biology and Physiology, 660 South Euclid Avenue, Box 8228, St. Louis, MO 63110.

Copyright $\odot 1996$ Society for Neuroscience (0270-6474/96/161056-10\$(15.00/0 of native neurons. Two steps in the differentiation of CNS neurons that might serve as benchmarks for assessing the phenotype of neurons derived from cell lines or precursor cells are the establishment of polarity and the formation of synaptic connections. Neurons, both in vivo and in culture, develop separate axonal and dendritic compartments that can be distinguished by their unique morphology, ultrastructure, and protein components (for review, see Craig and Banker, 1994). The establishment of polarity has been demonstrated for NTera-2 cells (Pleasure et al., 1992) but has not been directly examined for most other lines.

Several cell lines that resemble peripheral nervous system neurons have been shown to form cholinergic synapses onto cocultured primary muscle cells (Nelson et al., 1976; Schubert et al., 1977). Many closely related lines do not share this property (Nelson, 1976; Nirenberg et al., 1983), however, which suggests that cell lines differ widely in their ability to differentiate in vitro (Schubert et al., 1974; Fischbach and Nelson, 1977). For cell lines that resemble CNS neurons, relatively little is known about their ability to form synapses in vitro. Ultrastructural demonstration of synaptic profiles has been presented for the P19 cell line (McBurney et al., 1988), but physiological evidence for synaptic transmission has not been reporied for lines with a CNS phenotype. Although synapses mediated by glutamate receptors are among the most common in the nervous system, it has not been established whether any cell line can form functional glutamatergic synapses in vitro. Indeed, only recently have cell lines that express functional glutamate receptors been identified, including NTera-2 (Younkin et al., 1993), P19 (Turetsky et al., 1993), and embryonic stem (ES) cells (Bain et al., 1995). Thus, a major unanswered question remains: whether pluripotent stem cells undergo sufficient differentiation in vitro to form functional synapses with properties expected of CNS neurons, or whether their in vitro development comes to a halt well short of this milestone. 
We have examined this question using paired recordings from P19 or ES cells maintained in microisland cultures. In both cell types, subpopulations of cells formed excitatory synapses, mediated by glutamate receptors, whereas other cells formed inhibitory synapses mediated by receptors for GABA or glycine. Immunofluorescent double labeling revealed the establishment of neuronal polarity by both cell types, as well as the localization of synaptic vesicle antigens to presumptive sites of synaptic contact.

\section{MATERIALS AND METHODS}

Cell culture. P19 cells were induced to differentiate using a slight modification of procedures described by Turetsky et al. (1993). Briefly, undifferentiated cells from the American Type Culture Collection (Rockville, MD) were propagated in minimum essential medium (MEM), $\alpha$-formulation (Gibco, Grand Island, NY), supplemented with $10 \%$ fetal bovine serum (FBS; JRH Biosciences, Lenexa, KS). For differentiation, $\sim 4 \times 10^{\circ}$ cells were suspended in $10 \mathrm{ml}$ of $\alpha$-MEM containing $5 \%$ FBS and $500 \mathrm{~nm}$ retinoic acid and seeded onto a $10 \mathrm{~cm}$ bacteriological culture dish. After $4 \mathrm{~d}$ (or in a few cases, $5 \mathrm{~d}$ ) of retinoic acid treatment, aggregated cells were dissociated with Protease XXIII (1 mg/ml, Sigma, St. Louis, MO) in Earle's salt solution (Gibco), which lacked $\mathrm{Ca}^{2+}$ and $\mathrm{Mg}^{2+}$ but contained $200 \mu \mathrm{M}$ EDTA, $20 \mathrm{~mm}$ glucose, and $25 \mathrm{mM} \mathrm{NaHCO}$. Dissociated cells were plated onto confluent primary glial layers or glial island cultures in $\alpha$-MEM plus $10 \%$ FBS. On the second day after plating, the growth medium was changed to MEM (Gibco) supplemented with 20 $\mathrm{mm}$ glucose, $5 \%$ rat serum, and $250 \mu \mathrm{M}$ glutamine. Cytosine arabinoside (Ara-C) was added at a final concentration of $10 \mu \mathrm{M}$ to inhibit division of non-neuronal cells. Cultures were fed 2 d later with $\mathrm{MEM}+5 \%$ rat serum lacking Ara-C, then every 4-5 d thereafter.

ES cells (D3 line, obtained from Dr. David Gottlieb, Washington University) were maintained and induced as described previously (Bain et al., 1995) with some modifications. Cells were propagated in gelatincoated $(0.1 \%$ from bovine skin; Sigma) tissue culture flasks with DMEM (high glucose, with L-glutamine and sodium pyruvate; Gibco) supplemented with $10 \%$ fetal calf serum (Gibco), $10 \%$ newborn calf serum (Gibco), $100 \mu \mathrm{M} \beta$-mercaptoethanol (Sigma), $1000 \mathrm{U} / \mathrm{ml}$ leukemiainhibitory factor (Gibco), $10 \mu \mathrm{M}$ thymidine, and $30 \mu \mathrm{M}$ adenosine, cytidine, guanosine, and uridine. ES cells were passaged with Protease XXIII ( $1 \mathrm{mg} / \mathrm{ml}$; Sigma) and induced with $500 \mathrm{~nm}$ all-trans retinoic acid according to the $4-/ 4+$ protocol of Bain et al. (1995). After induction, aggregates were dissociated and plated onto gelatin-coated dishes or directly onto collagen islands (see below). At 2-3 d after plating, Ara-C was added ( $18 \mu \mathrm{M}$ final concentration). When most of the cells appeared to be morphologically mature ( $\sim 5 \mathrm{~d}$ after plating), the medium was changed to neurobasal medium with B27 supplements and $250 \mu \mathrm{M}$ L-glutamine (NB + B27; Gibco). Cultures were fed every $4-5$ d with NB + B27 until needed.

Primary glial cultures were prepared from 2- to 5-d-old Long-Evans rats as described previously (Huettner and Baughman, 1986). Microisland cultures were prepared according to the method of Segal and Furshpan (1990). Culture dishes $(35 \mathrm{~mm})$ were coated with a thin layer of $0.15 \%$ aga iose type II-A (Sigma), allowed to dry for $30 \mathrm{~min}$, and sterilized for 1 hr by ultraviolet (UV) irradiation. Droplets of type I rat tail collagen (1 $\mathrm{mg} / \mathrm{ml}$ in $0.1 \%$ acetic acid; Sigma) were sprayed onto the agarose-coated dishes. The dishes were UV-irradiated for $30 \mathrm{~min}$ before plating dissociated cortical cells or ES cells. Glial cultures were maintained in MEM plus $5 \%$ rat serum for several days, and then Ara-C was added to halt glial cell division. Before addition of $\mathrm{P} 19$ cells, the glial cultures were treated with glutamate or NMDA $(0.5-5 \mathrm{~mm})$ to climinate any rat cortical neurons.

Electrophysiology. Pipettes were pulled from boralex capillaries. For current-clamp recordings, the internal solution consisted of (in mM): 140 $\mathrm{KCH}_{3} \mathrm{SO}_{3}, 0.5$ EGTA, $5 \mathrm{KCl}, 1 \mathrm{ATP}$, and $10 \mathrm{HEPES}$, pH-adjusted to 7.4 with $\mathrm{KOH}$. Pipettes used for whole-cell voltage-clamp recordings contained either this same solution or, in most cases, contained (in $\mathrm{mM}$ ) 140 $\mathrm{CsCH}_{3} \mathrm{SO}_{3}, 10 \mathrm{EGTA}, 5 \mathrm{CsCl}, 1$ ATP, and $10 \mathrm{HEPES}$, $\mathrm{pH}$-adjusted to 7.4 with $\mathrm{CsOH}$. The culture dish was perfused at a rate of $1-2 \mathrm{ml} / \mathrm{min}$ with Tyrode's solution (in $\mathrm{mm}$ ): $150 \mathrm{NaCl}, 4 \mathrm{KCl}, 2 \mathrm{CaCl}_{2}, 2 \mathrm{MgCl}_{2}, 10$ glucose, and $10 \mathrm{HEPES}, \mathrm{pH}$-adjusted to 7.4 with $\mathrm{NaOH}$. For most experiments, drug solutions were applied to the cells via local perfusion from a multibarreled delivery pipette placed $200-300 \mu \mathrm{m}$ from the recording electrodes. Drugs were dissolved in normal or Mg-free Tyrode's solution for most studies of synaptic transmission.
Evoked postsynaptic responses were obtained by recording simultaneously from two adjacent cells. One recording was obtained under current clamp with a Getting microelectrode amplifier, and the other was achieved with an Axopatch $200 \mathrm{~A}$ patch-clamp amplifier in the whole-cell mode (Axon Instruments, Foster City, CA). Brief, depolarizing current steps were injected with the Getting amplifier at $0.1-1 \mathrm{~Hz}$ while holding current in the follower cell was monitored for inward or outward deflections. Postsynaptic currents that reliably followed the presynaptic action potential with a delay of $1-5 \mathrm{msec}$ were considered to arise from monosynaptic connections. The follower cell was often clamped at $-20 \mathrm{mV}$ to better detect outward, IPSCs. If no postsynaptic current was observed with the Axopatch amplifier, the stimulus paradigm was reversed. A brief step to $0 \mathrm{mV}$ was applied with the Axopatch amplifier as membrane potential was monitored with the Getting amplifier for depolarizing or hyperpolarizing deflections that were locked to the presynaptic stimulus.

Output from the two amplifiers was digitized at $3-17 \mathrm{kHz}$ with an IDA12120 computer interface (Indec Systems, Capitola, CA) controlled by in-house software using the Basic-Fastlab environment. Whole-cell currents were filtered at $1-5 \mathrm{kHz}(-3 \mathrm{~dB}$, 4-pole Bessel). Membrane potentials recorded under voltage clamp were corrected for the junction potential between the internal solution and the bath solution. This potential was $-10 \mathrm{mV}$ for pipettes containing $\mathrm{CsCH}_{3} \mathrm{SO}_{3}$ and $-13 \mathrm{mV}$ for pipettes containing $\mathrm{KCH}_{3} \mathrm{SO}_{3}$. Peak amplitudes of evoked and spontaneous synaptic currents were determined by averaging three to five points around the peak or, in some cases, all points within $90 \%$ of the absolute peak value. Some of the traces shown in the figures have been digitally filtered at $1 \mathrm{kHz}$. Aminophosphonovalerate (APV) was obtained from Cambridge Research Biochemicals (Wilmington, DE). 6-Cyano-7. nitroquinoxaline-2,3-dione (CNQX) was from Research Biochemicals (Natick, MA). Bicuculline, strychnine, and tetrodotoxin (TTX) were from Sigma.

Immunofuorescence. P19 cells on confluent glial layers or ES cells plated onto gelatin-coated coverslips were rinsed with Tyrode's solution

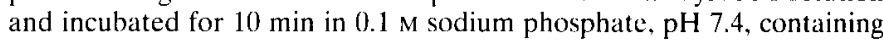
$4 \% p$-formaldehyde and $0.1 \%$ glutaraldchydc. A sceond fixation for 10 min was performed with $0.1 \mathrm{M}$ sodium borate, $\mathrm{pH} 9.75$, containing $4 \%$ $p$-formaldehyde. After four rinses with Tris-buffered saline, $\mathrm{pH} 7.4$, the cultures were incubated at $4^{\circ} \mathrm{C}$ for $1-48 \mathrm{hr}$ with blocking solution (BS): PBS containing $1 \%$ normal goat serum, $0.02 \%$ sodium azide, and $0.2 \%$ Polydet $\mathrm{P}-40$. Cells were incubated overnight at $4^{\circ} \mathrm{C}$ with primary antibodies diluted in BS and then rinsed three times with PBS and incubated for $1 \mathrm{hr}$ at room temperature with fluorescent secondary antibodies diluted in BS. The coverslips were rinsed three times with PBS, mounted with Vectashield (Vector Laboratories, Burlingame, CA), and examined with a Zeiss Axioplan under epi-illumination $(6.3 \times$ oil objective, 1.40 numerical aperture; Carl Zeiss, Thornwood, NY). Images were acquired with a laser scanning confocal attachment (MRC1000, Bio-Rad, Hercules, CA). Most of the figures show projections of five to nine separate focal plancs, in which the fluoresccin and $\mathrm{Cy} 3$ channels were acquired simultaneously (488 and $568 \mathrm{~nm}$ emission lines, $522 \mathrm{~nm}$ barrier for the fluorescein channel, $605 \mathrm{~nm}$ barrier for the $\mathrm{Cy} 3$ channel). In some cases, the two fluorophores were imaged sequentially to reduce the level of bleed-through between the two channels; no further corrections for bleed-through were used.

The following dilutions were used for primary and secondary antibodies: mouse anti-microtubule-associated protein-2 (anti-MAP-2; 1:200, clone AP20, Boehringer Mannheim, Indianapolis, IN): mouse anti-SV2 $(1: 200$, monoclonal supernatant of clone SP2/(0; Buckley and Kelly, 1985); mouse anti-synaptophysin (1:1000, ascites; Jahn et al., 1985); rabbit anti-growth-associated protein-43 (anti-GAP-43; 1:1000, antiserum; Meiri et al., 1986); rabbit anti-synapsin (antibody G357; Südhof et al., 1989); Cy3-conjugated goat anti-rabbit $\lg$ (1:300; Chemicon, Temecula, CA); fluorescein-conjugated goat anti-mouse $\lg (1: 200$; Chemicon).

\section{RESULTS}

\section{Neuronal polarity}

P19 and ES cells that have been induced with retinoic acid begin to produce neurites within 1-2 d after settling onto a permissive substrate. Both cell types generate an extensive network of processes during the first week after plating (McBurney et al., 1988; Bain et al., 1995). To determine whether these fibers become distinguished into separate axonal and dendritic compartments, we visualized the distribution of GAP-43 (Skene and Willard, 1981) and MAP-2 (Sloboda 
et al., 1975), which are known to be restricted in native neurons to axons or dendrites, respectively (see also Craig and Banker, 1994). Immunofluorescent double labeling with antibodies to GAP-43 and MAP-2 is shown in Figure 1, $A$ and $B$, for P19 cells $9 \mathrm{~d}$ after plating, and in Figure 2, $A$ and $B$, for ES cells $17 \mathrm{~d}$ after plating. For both cell types, MAP-2-like immunoreactivity was observed in the cell body, but was most intense in the thick tapering processes that emerged from the soma. Positive staining for MAP-2 was absent from the nucleus and from the majority of fine diameter neurites, although a few thin processes were lightly stained. By contrast, GAP-43-like immunoreactivity was relatively weak in the soma and major processes, but was much more intense in the network of thin fibers that spread across the cultures. In addition, both P19- and ES-cell cultures contained many GAP-43-positive growth cones. In most of our experiments on mature P19- and ES-cell cultures, staining for GAP-43 was uniformly distributed along the thin neurites (e.g., Fig. $1 A, C$ ). As has been reported previously both in vivo and in vitro (Meiri et al., 1988; Goslin et al., 1990), however, some cells in cultures displayed bright puncta of GAP-43-like immunoreactivity along fibers with a weaker, more uniform labeling pattern (e.g., Fig. $2 C$ ). Although large- and small-diameter neurites were often observed in close contact, careful evaluation of fiber diameter and position in the GAP-43 and MAP-2 images made it possible to rule out double labeling of individual fibers by the two antibodies in most cases.

We also examined the distribution of several proteins that are components of synaptic vesicles in native neurons, including synaptophysin (Jahn et al., 1985; Wiedenmann and Franke, 1985), SV2 (Buckley and Kelly, 1985), and synapsin (Südhof et al., 1989). In mature cultures of P19 or ES cells, immunoreactivity for these proteins was localized to discrete puncta that were arrayed along GAP-43-positive fibers (Figs. $1 C, D, 2 C, D$ ) or adjacent to MAP-2positive cell bodies and dendrites (Figs. $1 E, F, 2 E, F$ ). Our preliminary experiments (N. Kulkarni and J. Huettner, unpublished observations) on P19 and ES cells at earlier time points after plating suggest that segregation of GAP-43, MAP-2, and the synaptic vesicle antigens emerges gradually over the first 5-10 d after plating (see also Goslin et al., 1990; Dinsmore and Solomon, 1991; Fletcher et al., 1991). In all cases, however, staining was found to be restricted to cells with neuronal morphology; flat background non-neuronal cells were not positively stained for any of the markers used in this study.

\section{Synaptic transmission}

Recordings from individual P19 cells grown in mass cultures for 1-3 weeks revealed relatively little evidence for spontaneous synaptic activity, although in some cultures synaptic potentials or synaptic currents were occasionally observed (Fig. $3 A$; see also Turetsky et al., 1993). In contrast, ES cell-mass cultures exhibited a much higher frequency of spontaneous synaptic activity, as shown in Figure $4 A$. Both cell types displayed spontaneous excitatory and inhibitory postsynaptic responses. Our preliminary attempts to study evoked synaptic responses in mass cultures met with a low success rate. As has been noted previously in studies on neuronal cultures (Huettner and Baughman, 1988; Mennerick et al., 1995), synaptic contacts between adjacent cells are relatively rare in mass culture. To increase the likelihood that cells within a given field of view would become synaptic partners, we adapted the microisland culture system of Segal and Furshpan (1990). Dissociated ES cells were plated directly onto collagen spots that had been dried on a nonpermissive surface; P19 cells survived better when seeded onto preestablished islands of rat cortical astrocytes.
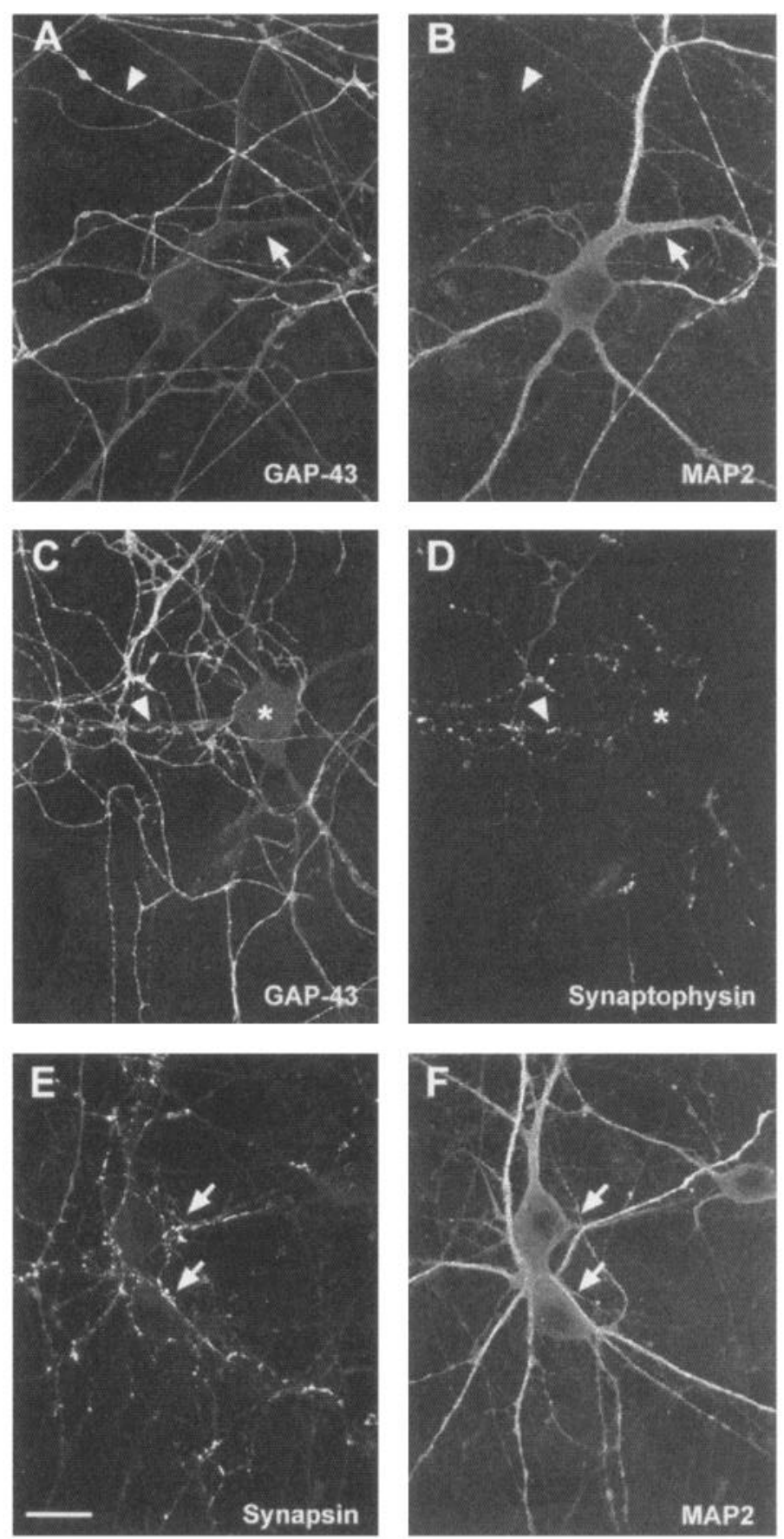

Figure 1. Localization of immunoreactivity for neuronal polarity markers and synaptic vesicle antigens in P19 cells. $A, B$, Immunofluorescence double labeling of GAP-43-like $(A)$ and MAP-2-like $(B)$ immunoreactivity. The arrow points to a neurite strongly positive for the dendritic marker MAP-2; an arrowhead indicates a fiber that exhibits strong immunoreactivity for the axonal marker GAP-43. $C, D$, Immunofluorescent double labeling of GAP43-like $(C)$ and synaptophysin-like $(D)$ immunoreactivity. An unstained cell (asterisks) surrounded by GAP-43-positive fibers is shown. The arrowhead points to an immunoreactive puncta adjacent to a dendrite extending from the cell body. $E, F$, Immunofluorescent double labeling of synapsin-like $(E)$ and MAP-2-like $(F)$ immunoreactivity. Arrows point to examples of immunoreactive puncta adjacent to two MAP-2-positive cell bodies. Cells were fixed $9 \mathrm{~d}(A, B), 20 \mathrm{~d}(C, D)$, and $9 \mathrm{~d}(E, F)$ after plating. Scale bar, $20 \mu \mathrm{m}$.

Evoked synaptic responses were studied by recording simultaneously from two cells on an island. Most of the P19-cell recordings were obtained from islands with $2-5$ cells, although some 

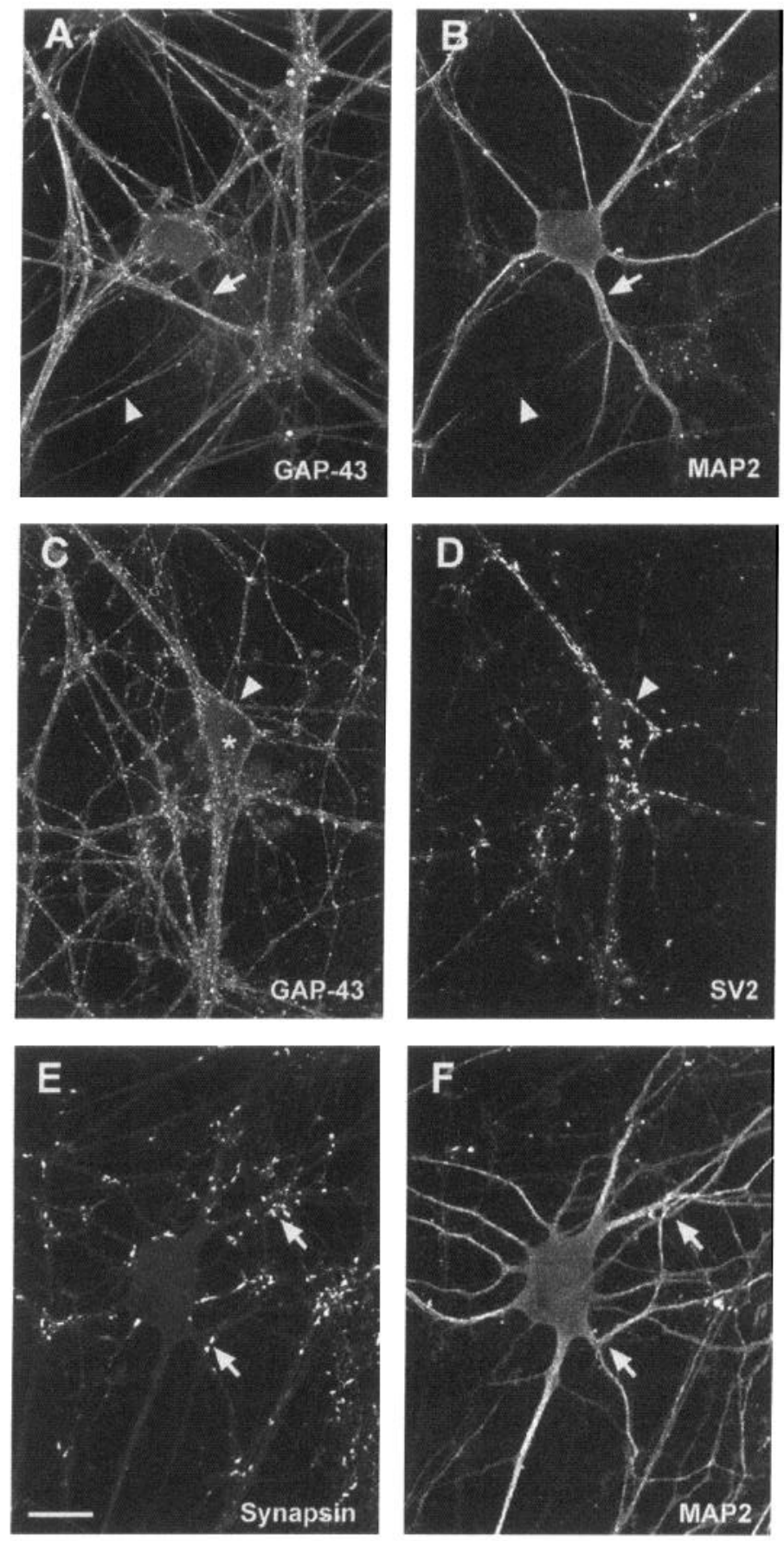

Figure 2. Immunoreactivity for synaptic vesicle antigens and neuronal polarity markers in ES cells. $A, B$, Immunofluorescence double labeling of GAP-43-like $(A)$ and MAP-2-like $(B)$ immunoreactivity. The arrow points to a neurite strongly positive for the dendritic marker MAP-2; an arrowhead indicates a fiber that exhibits strong immunoreactivity for the axonal marker GAP-43. $C, D$, Immunofluorescent double labeling of GAP-43like $(C)$ and SV2-like $(D)$ immunoreactivity. Arrowhead points to puncta immunoreactive for SV2 adjacent to an unstained cell body (asterisks). E, $F$, Immunofluorescent double labeling of synapsin-like $(E)$ and MAP-2like $(F)$ immunoreactivity. Arrows point to examples of immunoreactive puncta adjacent to the cell body and dendrites of a MAP-2-positive neuron. Cells were fixed $17 \mathrm{~d}(A, B), 13 \mathrm{~d}(C, D)$, and $14 \mathrm{~d}(E, F)$ after plating. Scale bar: $A-D, 20 \mu \mathrm{m} ; E, F, 25 \mu \mathrm{m}$.

pairs were studied on islands of 30 or more cells. Because of the relatively low number of sparsely populated ES-cell islands, most recordings from ES-cell pairs were from islands with at least 20
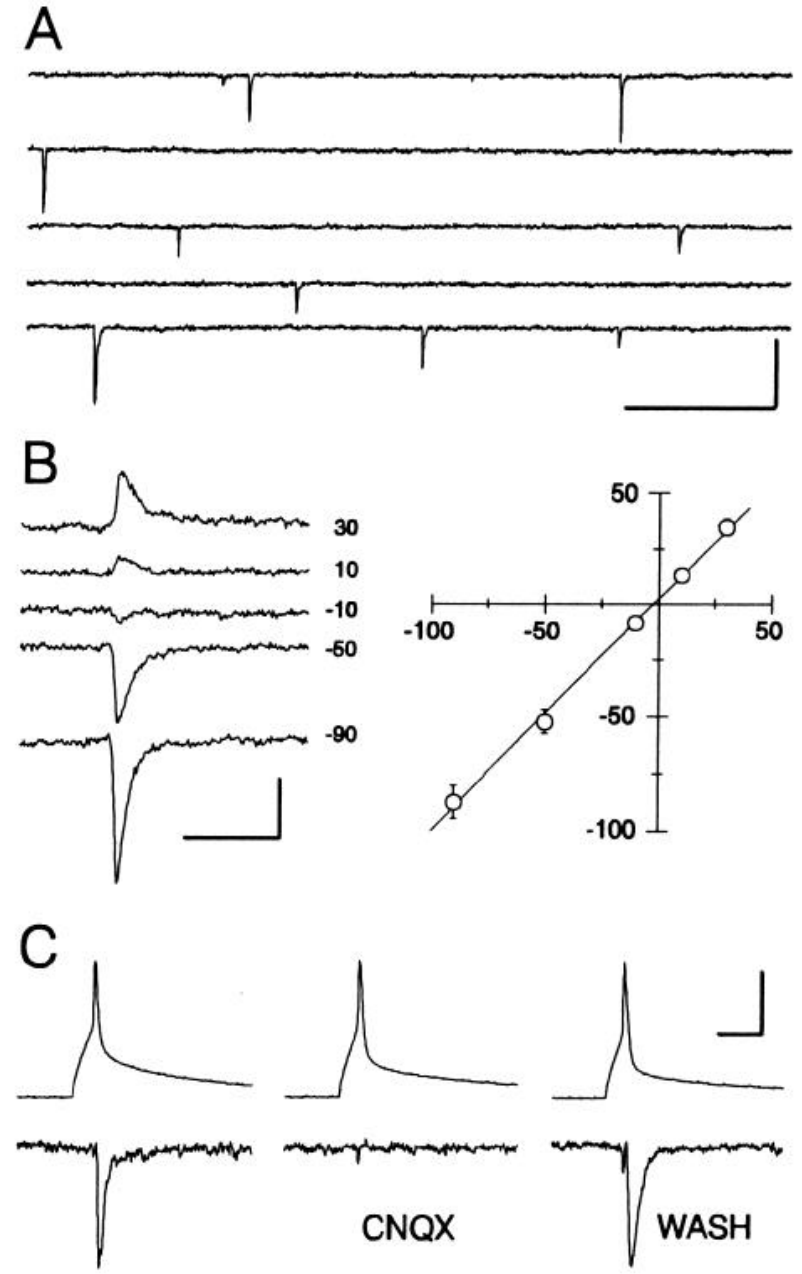

Figure 3. Spontaneous activity and excitatory synaptic transmission in P19 cells. $A$, Spontaneous synaptic currents recorded in normal Tyrode's solution $12 \mathrm{~d}$ after plating; $5 \mathrm{sec}$ of continuous recording is shown. Holding potential, $-70 \mathrm{mV} . B, I-V$ relationship for an evoked EPSC recorded 12 $\mathrm{d}$ after plating. Each trace is an average of three to four sweeps. The plot shows the mean \pm SEM peak amplitude versus holding potential. $C$, EPSC antagonism by $C N Q X(10 \mu \mathrm{M})$ in a different neuron. Action potentials elicited in the presynaptic neuron (top traces) and synaptic currents recorded in the postsynaptic neuron (bottom traces) are shown. Holding potential, $-90 \mathrm{mV}, 12 \mathrm{~d}$ after plating. Scale bars: $A, 50 \mathrm{pA}, 200 \mathrm{msec} ; B$, $40 \mathrm{pA}, 30 \mathrm{msec} ; C, 60 \mathrm{mV}, 20 \mathrm{pA}, 30 \mathrm{msec}$.

cells. Cells targeted for recording were phase-bright with multiple neurites. Two cells were judged to have formed a functional synapse if action potentials triggered in one of the cells ("driver") reliably elicited a postsynaptic response in the other cell ("follower") with short latency (usually $<5 \mathrm{msec}$ ). Responses with longer lag times that unreliably followed the presynaptic stimulus were considered to be polysynaptic. Functional synapses were observed in 12 of 13 P19-cell inductions and 4 of 5 ES-cell inductions. In the 12 P19-cell inductions that yielded functional monosynaptic connections, the percentage of cells able to serve as drivers ranged from 9 to $40 \%$ with an average of $23 \pm 3 \%(97 / 808$ total cells). Similarly, in the 4 ES-cell inductions an average of 25 $\pm 7 \%$ of cells were drivers (range $5-40 \% ; 55 / 210$ total cells). A majority of these connections were excitatory in both P19 (82\%) and ES (78\%) cells. Evidence for direct electrical coupling was observed in 7 P19-cell pairs but was not detected in any of the ES-cell pairs. Many of the P19- and ES-cell pairs that did not 
A

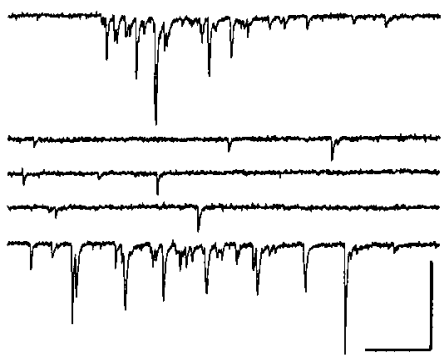

B

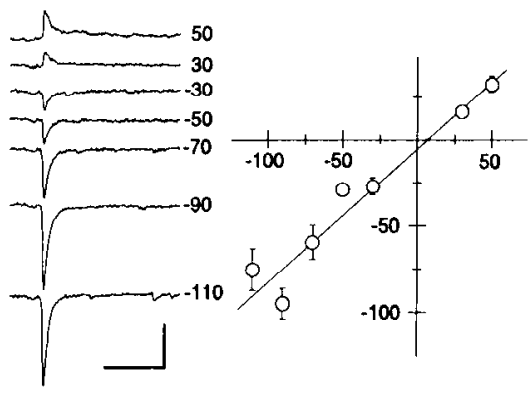

Figure 4. Spontaneous activity and excitatory synaptic transmission in ES cells. $A$, Spontaneous synaptic currents recorded in normal Tyrode's solution $16 \mathrm{~d}$ after plating; $5 \mathrm{sec}$ of continuous recording is shown. Holding potential, -70 $\mathrm{mV} . B, I-V$ relationship for an cvoked EPSC recorded $34 \mathrm{~d}$ after plating. Each trace is an average of four sweeps. The plot shows the mean \pm SEM peak amplitude versus holding potential. $C$, EPSC antagonism by $C N Q X(10 \mu \mathrm{M})$. Top traces are action potentials from the presynaptic neuron (arrows point to an autaptic EPSP that is blocked by CNQX), bottom traces are postsynaptic currents (single sweeps). Holding potential, $-90 \mathrm{mV}, 40 \mathrm{~d}$ after plating. $D$, APV speeds the decay of an EPSC evoked at $+50 \mathrm{mV}, 23 \mathrm{~d}$ after plating. Three traces are shown superimposed. Control traces recorded in normal Tyrode's solution $\left(2 \mathrm{mM} \mathrm{Ca}^{2+} / 2 \mathrm{mM} \mathrm{Mg}^{2+}\right)$ at $-70 \mathrm{mV}$ and $+50 \mathrm{mV}$, and a trace at $+50 \mathrm{mV}$ in the presence of $A P V(50 \mu \mathrm{M})$. Each trace is an average of four individual EPSCs. $F, C N Q X(10 \mu \mathrm{M})$ blocks the fast component of this EPSC recorded in $\mathrm{Mg}^{2+}$-free Tyrode's solution at $-70 \mathrm{mV}, 28 \mathrm{~d}$ after plating. The slower component of the EPSC is blocked reversibly by addition of $2 \mathrm{~mm} \mathrm{Mg}^{2+}$ $\left(C N Q X+\mathrm{Mg}^{2+}\right)$. Single traces are shown. Scale bars: $A, 200$ $\mathrm{pA}, 200 \mathrm{msec} ; B, 40 \mathrm{pA}, 40 \mathrm{msec} ; C, 40 \mathrm{mV}, 80 \mathrm{pA}, 30 \mathrm{msec}$ $D, 20 \mathrm{pA}, 30$ msec; $E, 100 \mathrm{pA}, 100$ insec.
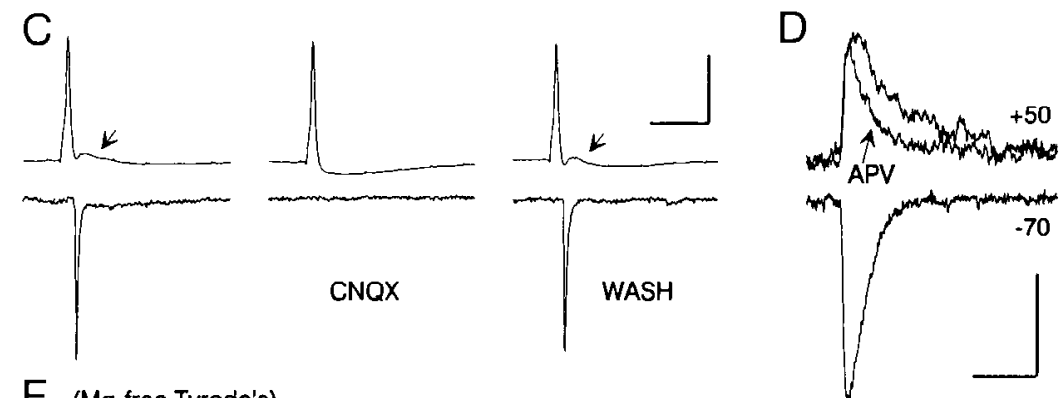

E (Mg-free Tyrode's)

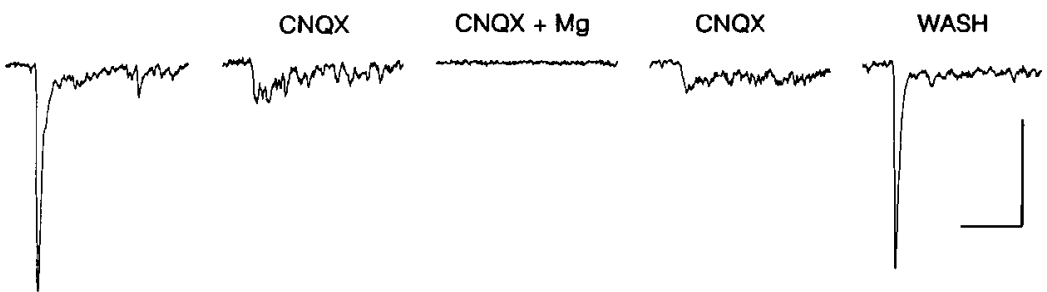

display a direct monosynaptic connection, nevertheless, did receive spontaneous synaptic activity or were connected by a polysynaptic circuit, which suggests that most cells were capable of forming synapses. Functional synapses were observed as early as $9 \mathrm{~d}$ after plating in P19 cells and $11 \mathrm{~d}$ after plating in ES cells. Most recordings were obtained between 15 and $30 \mathrm{~d}$ after plating, but connected pairs were recorded for both cell types as late as $40 \mathrm{~d}$ after plating.

\section{Excitatory synapses}

P19 and ES cells form excitatory chemical synapses mediated by glutamate receptors. As illustrated in Figures $3 C$ and $4 C$, the non-NMDA-receptor antagonist CNQX produced complete inhibition of EPSCs (recorded at -60 to $-90 \mathrm{mV}$ in the presence of $2 \mathrm{mM} \mathrm{Ca}^{2+}$ and $\left.2 \mathrm{mM} \mathrm{Mg}^{2+}\right)$ in all of the ES cells studied $(n=23)$ and all but one of the P19 synapses tested $(n=30)$. Inhibition by $10 \mu \mathrm{M}$ CNQX was fully reversible with sufficient wash time. The reversal potential for EPSCs was determined for 4 P19 cells and 6 ES cells by clamping the postsynaptic cell at holding potentials from -110 to $+50 \mathrm{mV}$ (corrected for junction potential). As shown in Figures $3 B$ and $4 B$, most EPSCs demonstrated a linear current-voltage $(I-V)$ relationship and reversed close to $0 \mathrm{mV}$, which is consistent with the known properties of non-NMDAreceptor channels expressed by these cells (Turetsky et al., 1993; Bain et al., 1995). In one P19 cell, the EPSC displayed an inwardly rectifying $I-V$ that reversed near $0 \mathrm{mV}$.

We further analyzed 11 EPSCs from P19 cells and 11 EPSCs from ES cells recorded at -70 to $-90 \mathrm{mV}$ in normal Tyrode's solution to determine their average rise times, decay times, and peak amplitudes (Table 1, Fig. 5D). Only EPSCs that demonstrated complete block and recovery from CNQX application were considered. The falling phase of most EPSCs was well described by a single-exponential function (Fig. 5D). The average decay constant in both P19 and ES cells was $4.1 \mathrm{msec}$, a value similar to that reported for native CNS neurons (Hestrin, 1992; Mennerick et al., 1995). Average rise times were also comparable with previously reported values. The peak amplitude of EPSC's ranged as high as $200 \mathrm{pA}$, but the average peak amplitude in both ES and P19 cells was on the order of 10-50 pA, which is significantly smaller than EPSCs typically recorded in hippocampal microcultures (see Bekkers and Stevens, 1989; Tong and Jahr, 1994; Mennerick et al., 1995).

\section{Miniature EPSCs}

Possible explanations for the relatively small amplitude of P19 and ES cell-evoked synaptic currents include a low number of synaptic

Table 1. P19- and ES-cell postsynaptic currents

\begin{tabular}{lcllll} 
& $\begin{array}{l}\text { Amplitude } \\
(\mathrm{pA})\end{array}$ & $\begin{array}{l}10-90 \% \\
\text { Rise time } \\
(\mathrm{msec})\end{array}$ & $\begin{array}{l}\text { Decay } \\
\text { constant } \\
(\mathrm{msec})\end{array}$ & $\begin{array}{l}\text { Reversal } \\
\text { potential } \\
(\mathrm{mV})\end{array}$ \\
\hline EPSC & & & & & \\
$\quad$ ES & $-49 \pm 17$ & $1.7 \pm 0.3$ & $4.1 \pm 0.7$ & 11 & $6 \pm 3(n=6)$ \\
P19 & $-60 \pm 18$ & $2.1 \pm 0.3$ & $4.1 \pm 0.4$ & 11 & $0 \pm 3(n=4)$ \\
mEPSC (ES) & $-8.8 \pm 0.8$ & $1.9 \pm 0.2$ & $4.2 \pm 0.3$ & 6 & $\mathrm{ND}$ \\
IPSC & & & & & \\
$\quad$ ES (glycinergic) & $66 \pm 28$ & $0.7 \pm 0.3$ & $18 \pm 4$ & 4 & $-53 \pm 5(n=4)$ \\
P19 (GABAergic) & $31 \pm 9$ & $2.2 \pm 0.8$ & $48 \pm 2$ & 3 & $-71 \pm 2(n=3)$
\end{tabular}

The amplitude, $10-90 \%$ rise time, and decay constant were determined for the average of 6-10 evoked synaptic currents in each cell. All of the miniature EPSCs (mEPSCs) were analyzed individually (see Fig. 5). Values denote mean $\pm 5 E M ; n$ number of cells analyzed; ND, not determined. 

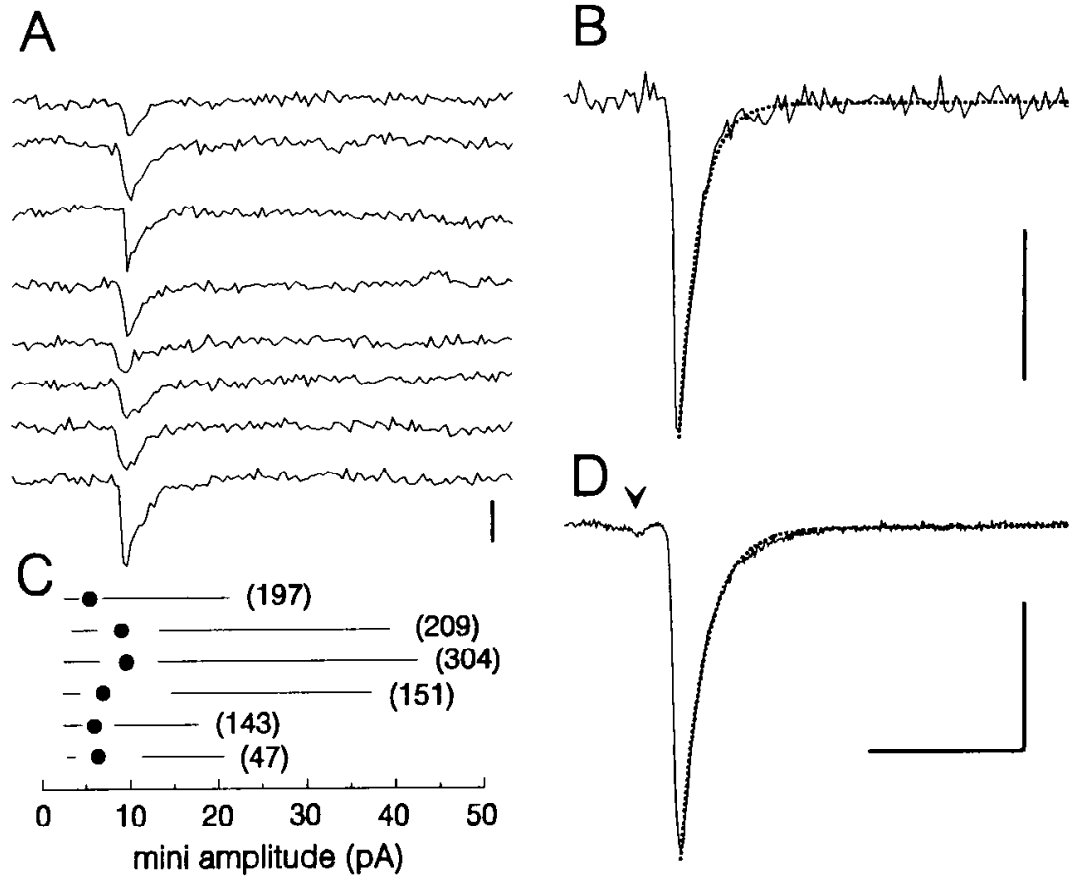

Figure 5. Miniature and evoked EPSCs in ES cells. $A$, Individual miniature EPSCs recorded sequentially at -70 $\mathrm{mV}$ in the presence of $0.5 \mu \mathrm{M}$ TTX, $34 \mathrm{~d}$ after plating. $B$, Average of 14 miniature events (including those in $A$ ). The monoexponential fit to the decay is shown as a dotted line $\left(\tau_{\text {decay }}=2.6 \mathrm{msec}\right) . C$, Quartile plot of mini amplitudes from 6 cells including the cell from $A$ and $B$ (bottom plot). Points (-) show the median amplitude for each cell. Lines span the range of highest and lowest quartile amplitudes. Number of events analyzed is shown in parentheses. $D$, Average of nine EPSCs evoked in the cell shown in $A$ and $B\left(\tau_{\text {deciay }}=3.3\right.$ msec). Current scale bars: $A, 10 \mathrm{pA} ; B, 4 \mathrm{pA} ; D, 60 \mathrm{pA}$. I'ime scale bar (shown in $D$ ): $20 \mathrm{msec}$ for $A, B$, and $D$. contacts between the two cells, a low probability of transmitter release, and a small unitary synaptic event. To address this third possibility, we recorded spontaneous miniature EPSCs in $6 \mathrm{ES}$ cells that were superfused with $0.5 \mu \mathrm{M}$ TTX to block sodiumdependent action potentials as well as strychnine $(2 \mu \mathrm{M})$ and bicuculline $(20 \mu \mathrm{M})$ to block spontaneous inhibitory synaptic currents (see below). In one case, both evoked and miniature excitatory synaptic events were recorded in the same cell (Fig. $5 A, B, D)$. As shown in Figure 5 , the time course of miniature EPSCs was similar to that of evoked synaptic currents. For the 6 cells analyzed, the peak amplitude of miniature events ranged from 2 to $42 \mathrm{pA}$ at $-70 \mathrm{mV}$, which translates into a peak conductance range of $29-600 \mathrm{pS}$. In each case, the amplitudes of miniature EPSCs displayed a skewed distribution (Fig. 5C), as has been described previously in hippocampal and cortical neurons (Bekkers et al., 1990; Hestrin, 1992; Jonas et al., 1993; Liu and Tsien, 1995). The median peak conductance values ranged from 76 to $136 \mathrm{pS}$ (see Table 1 for mean peak amplitudes), which is consistent with previous measurements of mini amplitude in primary neuronal cultures (Hestrin, 1992; Liu and Tsien, 1995; Mennerick et al., 1995). The frequency of miniature EPSCs in these 6 cells ranged from 2 to $20 \mathrm{~Hz}$.

\section{NMDA receptors}

Because both P19 and ES cells are known to express functional NMDA receptors (Turetsky et al., 1993; Bain et al., 1995), it was of interest to determine whether these receptors contribute to the postsynaptic responses at excitatory synapses. Because NMDAreceptor channels are subject to voltage-dependent block by $\mathrm{Mg}^{2+}$ (Nowak et al., 1984), we compared the time course of EPSCs at negative and positive holding potentials and performed a number of experiments in $\mathrm{Mg}^{2+}$-free solutions. In several of the ES cells, depolarization to positive holding potentials unmasked a slow component of the EPSC that was sensitive to APV (Fig. 4D); however, in most of the cells this component was relatively small. Clearer evidence for an NMDA-receptor contribution to ES-cell EPSCs was obtained in $\mathrm{Mg}^{2+}$-free solutions. In 3 ES cells, superfusion with $\mathrm{Mg}^{2+}$-free Tyrode's revealed a slow component of synaptic transmission that was blocked by $2 \mathrm{mM} \mathrm{Mg}^{2+}$ (Fig. $4 E$ ) or $50 \mu \mathrm{M}$ APV (data not shown), but was insensitive to $10 \mu \mathrm{M}$ CNQX (Fig. 4E). In 9 other ES cells and 6 P19 cells tested with $\mathrm{Mg}^{2+}$-free solutions, it was difficult or impossible to resolve an NMDA component to the monosynaptic EPSC; however, several of these cells (2/2 ES, 2/2 P19) were shown to express functional NMDA receptors as demonstrated by their sensitivity to exogenous NMDA $(100 \mu \mathrm{M})$ application. We also applied $\mathrm{Mg}^{2+}$-free Tyrode's solution to many cell pairs $(n=96)$ that did not exhibit a monosynaptic response in normal medium. A few cells (6 ES, 9 P19) displayed an increase in polysynaptic or spontaneous activity after switching into the $\mathrm{Mg}^{2+}$-free medium, and in most cells (4/4 ES, 5/9 P19) this activity was suppressed by addition of $50 \mu \mathrm{M}$ APV (data not shown). None of the cells, when perfused with $\mathrm{Mg}^{2+}$-free medium, displayed a monosynaptic connection that was entirely mediated by NMDA receptors.

\section{Inhibitory synapses}

Although a majority of synaptic connections in pairs of ES or P19 cells were excitatory, a sizable minority of cells were inhibitory. IPSCs recorded in both cell types were challenged with the $\mathrm{GABA}_{\mathrm{A}}$-receptor antagonist bicuculline and with the inhibitory glycine-receptor antagonist strychnine (Fig. 6). At $20 \mu \mathrm{M}$, bicuculline blocked 3 of 6 P19 IPSCs but did not inhibit the IPSCs recorded in $5 \mathrm{ES}$ cells. By contrast, $2 \mu \mathrm{M}$ strychnine blocked 1 of 4 IPSCs in P19 cells and 4 of 4 IPSCs tested in ES cells. Control experiments showed that these antagonist concentrations were selective for GABA and glycine receptors, respectively, although higher doses of strychnine $(20-50 \mu \mathrm{M})$ produced significant inhibition of whole-cell GABA currents and GABAcrgic IPSCs (M. Finley and J. Huettner, unpublished observations), as described previously in hippocampal neurons (Shirasaki et al., 1991). The $I-V$ relationship for IPSCs showed modest outward rectification, consistent with the difference in internal and external chloride concentrations (Fig. 6C,D). With our normal intracellular solution ( $5 \mathrm{mM} \mathrm{Cl}^{-} / 140 \mathrm{mM} \mathrm{CH}_{3} \mathrm{SO}_{3}^{-}$), the reversal potential for P19- and ES-cell IPSCs fell somewhat positive to the Nernst potential for chloride $(-90 \mathrm{mV})$, which probably reflects the finite permeability 

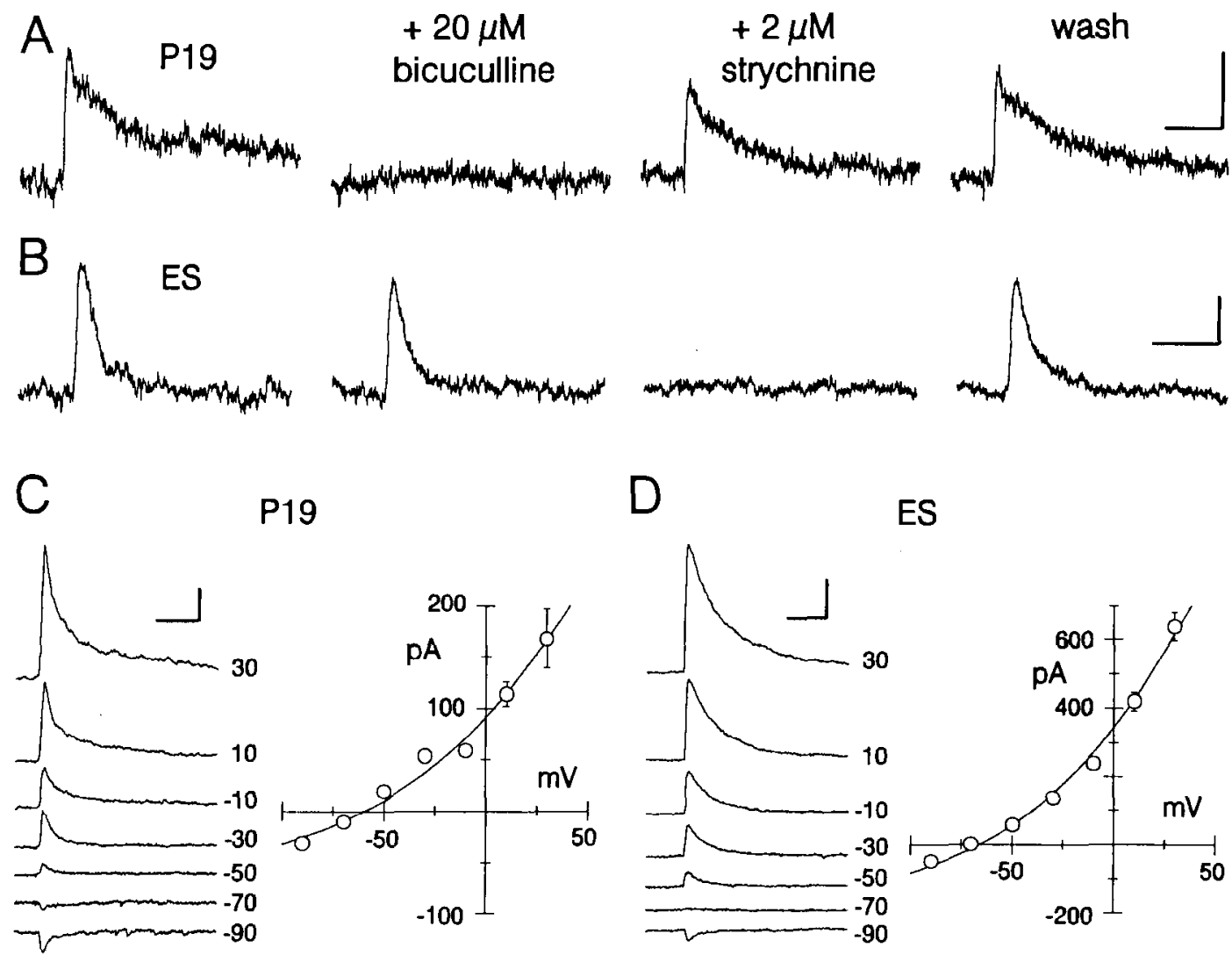

Figure 6. Inhibitory synaptic transmission in P19 and ES cells. $A$, An evoked IPSC recorded at $-10 \mathrm{mV}$ in a P19 cell culture was blocked by superfusion with $20 \mu \mathrm{M}$ bicuculline methiodide but was unaffected by $2 \mu \mathrm{M}$ strychnine. Each trace is the average of four IPSCs recorded $18 \mathrm{~d}$ after plating. $B$, In an ES cell culture $22 \mathrm{~d}$ after plating, bicuculline had no effect on this IPSC, but $2 \mu \mathrm{M}$ strychnine produced complete inhibition. Single traces are shown. Holding potential, $-30 \mathrm{mV}$. C, D, Evoked IPSCs recorded at holding potentials from -90 to $+30 \mathrm{mV}$ in a P19 cell (C) $18 \mathrm{~d}$ after plating, and an ES cell (D) $25 \mathrm{~d}$ after plating. Both of these IPSCs were blocked by strychnine but not bicuculline. The average of three individual IPSCs is shown in $C$; single traces are shown in $D$. The plots show peak current (mean $\pm \mathrm{SEM} ; n=2-8$ ) as a function of holding potential. Scale bars: $A, 10 \mathrm{pA}, 60 \mathrm{msec} ; B, 20 \mathrm{pA}$, $60 \mathrm{msec} ; C, 50 \mathrm{pA}, 60 \mathrm{msec} ; D, 200 \mathrm{pA}, 30 \mathrm{msec}$.

of these channels to $\mathrm{CH}_{3} \mathrm{SO}_{3}^{-}$(see also Bormann et al., 1987). Further analysis of P19- and ES-cell IPSCs (Table 1) revealed a significant difference in the decay time constants of bicucullinesensitive IPSCs in P19 cells (48 msec) versus strychnine-sensitive IPSCs in ES cells $(18 \mathrm{msec})$, but both values fell within the range observed in previous work on CNS neurons in slices (Edwards et al., 1990; Takahashi et al., 1992; Krupp and Feltz, 1993) and primary cultures (Barker and Harrison, 1988). Peak IPSC amplitudes in P19 and ES cells ranged from 18 to $150 \mathrm{pA}$ at -10 to $-30 \mathrm{mV}$.

\section{DISCUSSION}

\section{Synapse formation}

Our physiological recordings have shown that P19 and ES cells form synapses with many of the properties expected for CNS neurons. For both cell types, $\sim 80 \%$ of the synapses were excitatory connections, mediated by glutamate receptors. In their kinetic properties, $I-V$ relationships, and sensitivity to CNQX, virtually all of the EPSCs showed close similarity to the AMPAreceptor component of excitatory transmission that has been characterized in native neurons (Forsythe and Westbrook, 1988; Hestrin et al., 1990). The linear relationship between peak synaptic current and membrane voltage, with a reversal potential close to $0 \mathrm{mV}$, indicates that most synaptic AMPA receptors are likely to include the edited form of the GluRB subunit (Sommer et al., 1991), as suggested previously from analysis of whole-cell currents in these cells (Turetsky et al., 1993; Bain et al., 1995).
In several of the ES cells, NMDA receptors contributed to the postsynaptic response. Synaptic currents mediated by NMDA receptors showed voltage-dependent blockade by extracellular $\mathrm{Mg}^{2+}$ and decayed more slowly than the AMPA-receptor component of postsynaptic current. These currents were inhibited by APV but were not reduced by CNQX (see also Hestrin et al., 1990). Further evidence for involvement of NMDA receptors in excitatory transmission came from cells in which perfusion with $\mathrm{Mg}^{2+}$-free medium led to an APV-sensitive increase in polysynaptic activity (cf. Huettner and Baughman, 1988). In many cell pairs, however, including all of the P19 cells exposed to $\mathrm{Mg}^{2+}$-free medium, the monosynaptic EPSC did not include an NMDAreceptor component, suggesting that NMDA and non-NMDA receptors may not be colocalized at every excitatory synapse. By applying exogenous NMDA to these cells, we were able to show that they expressed functional NMDA receptors. Thus, the lack of an NMDA-receptor contribution to the EPSC reflects a specific deficit of activatable receptors at these synapses. Previous work (Bekkers and Stevens, 1989) on primary hippocampal neurons has shown that up to $20 \%$ of excitatory synapses do not exhibit any detectable NMDA-receptor component, whereas $10 \%$ of synapses may be mediated solely by NMDA receptors, without any contribution by AMPA receptors (see also Liao et al., 1995). It also has been shown both in slices (Liao et al., 1995; Weisskopf and Nicoll, 1995) and in cell culture (Forsythe and Westbrook, 1988) that different synapses onto an individual neuron may display very 
different relative contributions by NMD $\Lambda$ and non-NMD $\Lambda$ recep tors. In our P19- and ES-cell cultures, perfusion with $\mathrm{Mg}^{2+}$-free medium did not unmask an EPSC in any of the cell pairs that lacked an EPSC or IPSC in solutions that contained $\mathrm{Mg}^{2+}$.

The amplitude, kinetics, and frequency of miniature EPSCs recorded in ES cells were on the same order as those reported previously for miniature EPSCs in primary neuronal cultures (Hestrin, 1992; Jonas et al., 1993; Liu and Tsien, 1995; Mennerick et al., 1995). However, the frequency and strength of evoked synaptic connections in both P19- and ES-cell cultures were lower than observed previously for CNS neurons (Huettner and Baughman, 1988; Bekkers and Stevens, 1989; Tong and Jahr, 1994; Mennerick et al., 1995). Our recordings from pairs of cells maintained in microcultures showed that on average $20-25 \%$ of the cells evoked a monosynaptic response in a nearby follower. The mean amplitude of excitatory currents was $\sim 10-180 \mathrm{pA}$, whereas that of inhibitory currents was $20-150 \mathrm{pA}$ (Table 1). Microculture studies of primary neurons have shown that $50-90 \%$ of all cell pairs formed monosynaptic connections, with the lower number coming from relatively large islands that had 50-100 potential target cells. Monosynaptic current amplitudes in neuronal microcultures are typically $>1$ nA (Bekkers and Stevens, 1989; Mennerick et al., 1995), which is nearly 20 times larger than the EPSCs and IPSCs that we recorded in most ES- or P19-cell pairs. Our analysis of spontaneous miniature EPSCs suggests that the properties of unitary events cannot explain this difference in the amplitude of evoked synaptic currents. Further work will be needed to determine whether the lower amplitude of the P19- and ES-cell synaptic currents is attributable to a low probability of release, fewer individual synaptic contacts between cell pairs, or some combination of factors. The lower percentage of monosynaptic connections between pairs of P19 or ES cells does not indicate that a significant population of cells is simply incapable of forming synapses. On the contrary, a majority of ES cells displayed spontaneous synaptic activity, which indicates that most of the cells were able to receive synaptic inputs. In addition, many of the P19- and ES-cell pairs that did not exhibit short-latency responses nevertheless were connected via polysynaptic circuits. Finally, previous studies have shown that virtually all of the P19 and $\mathrm{CS}$ cells with neuronal morphology cxpress functional reccptors for AMPA, NMDA, GABA, and glycine (Turetsky et al., 1993; Bain et al., 1995) (our unpublished observations).

In addition to the cells that formed excitatory synapses, a smaller number of cells made inhibitory synapses involving receptors for glycine or for GABA. Paired recordings from ES cells yielded only glycinergic inhibitory synapses; however, our preliminary experiments on spontaneous synaptic currents in mass cultures revealed several examples of IPSCs that were blocked by bicuculline (M. Finley and J. Huettner, unpublished observations). Thus, our failure to observe GABAergic synapses in EScell microcultures is probably attributable to the relatively small number of IPSCs examined, rather than to an absolute lack of GABAergic ES neurons. Evidence for GABAergic function from previous studies of $\mathrm{ES}$ and $\mathrm{P} 19$ cells includes the demonstration of glutamic acid decarboxylase (GAD) mRNA expression by both P19 (Bain et al., 1993) and ES cells (Bain et al., 1995), as well as immunoreactivity for GAD, GABA, and GABA transaminase in subpopulations of P19-derived neurons (Staines et al., 1994).

\section{Neuronal differentiation}

Establishment of polarity and formation of synaptic connections with appropriate target cells are two key steps along the pathway of neuronal differentiation. Our results have shown that within 2-3 weeks after induction by retinoic acid, pluripotent embryonic carcinoma cells (P19) and totipotent ES cells pass from a nearly (P19) or totally (ES) uncommitted phenotype to one that strongly resembles mature neurons without ever having experienced a normal in vivo environment. Therefore, a major conclusion of this study is that acquisition of the basic CNS neuronal phenotype does not require exposure to the intact embryo, but can occur entirely in vitro (cf. McBurney et al., 1988; Pleasure et al., 1992; Bain et al., 1995).

One early attraction of neuronal cell lines was the possibility that these lines might develop into a single, homogeneous population of cells. Our results, together with earlier work on ES and P19 cells (Jones-Villeneuve et al., 1982, 1983; Bain et al., 1995), have demonstrated that multiple cell types, including both neurons and glia, are produced after induction with retinoic acid. This result is not surprising, given the fact that lineage studies in vivo and in vitro have shown that both neurons and glia can be generated from a common progenitor, even at the final rounds of cell division during neurogenesis (Price et al., 1987; Turner and Cepko, 1987; Temple, 1989; Galileo et al., 1990). At this point, it is not clear how many distinct subtypes of neurons and glia can be derived from P19 or ES cells; however, it is of interest to note that transplantation studies of both normal (Fishell, 1995) and immortalized (Renfranz et al., 1991; Snyder et al., 1992) CNS progenitor cells have shown that the local environment in which cells develop may exert a profound influence on their ultimate morphology and, presumably, on their overall phenotype. These transplantation studies suggest that CNS progenitors may be multipotential with respect to the cell types they can generate and that environmental cues may play a significant role in determining their phenotype (see also Gage et al., 1995). Thus, further work will be needed to determine whether the neurons generated in vitro, either from P19 and ES cells or from embryonic CNS progenitors, represent a generic ground state, or whether they have acquired definitive cellular identities that directly correspond to specific cell types of the brain or spinal cord.

In evaluating neuronal differentiation, the importance of functional analysis cannot be overemphasized. Numerous previous studies (Schubert ct al., 1974; Nirenberg et al., 1983; Ryder et al., 1990) have shown that morphological appearance is not predictive of electrophysiological properties. In addition, many neuronal lines that produce mRNA for GABA- or NMDA-receptor subunits fail to express working receptors on their surface (Sucher et al., 1993; Hales and Tyndale, 1994). Indeed, a major conclusion from functional analysis of neuronal cell lines and precursor cells is that they display dramatic differences in their ability to differentiate. Early work on cell lines derived from neuroblastoma cells revealed that only a few lines were able to form synapses onto primary muscle cells in vitro (Nelson, 1976; Nirenberg et al., 1983). Similarly, cell lines derived from CNS tumors were shown to differ widely in their expression of neuronal characteristics (Schubert et al., 1974). More recent work (Ryder et al., 1990) on cell lines immortalized from CNS progenitors has suggested that these lines exhibit relatively incomplete differentiation in vitro, although the same cells may progress much further when engrafted into a normal host brain (Renfranz ct al., 1991; Snyder et al., 1992). This difference between in vitro and in vivo differentiation may have been attributable to suppression of cell division in vivo (Cepko, 1988; LoPresti et al., 1992), but also may reflect a requirement for specific differentiation cues that were not available to cells in culture (Renfranz et al., 1991) (see also Kleppner et al., 1995; Magnuson et al., 1995). Although our results do not at all 
discount a role for differentiation cues (see above), they clearly demonstrate that conditions in vitro do not preclude significant differentiation-continuously dividing and completely uncommitted stem cells can be induced to differentiate in vitro to the point that they are able to form functional synapses. Although much further work will be needed to understand the combination of intrinsic programs and environmental influences that underlie this pathway of development, our results greatly strengthen the argument that P19 and ES cells provide an important model for both the early and late stages of neuronal differentiation.

\section{REFERENCES}

Andrews PW (1984) Retinoic acid induces neuronal differentiation of a cloned human embryonal carcinoma cell line in vitro. Dev Biol 103:285-293.

Bain G, Kitchens D, Yao M, Huettner JE, Gottlieb DI (1995) Embryonic stem cells express neuronal properties in vitro. Dev Biol 168:342-357.

Bain G, Ramkumar TP, Cheng JM, Gottlieb DI (1993) Expression of the genes coding for glutamic acid decarboxylase in pluripotent cell lines. Mol Brain Res 17:23-30.

Barker J, Harrison NL (1988) Outward rectification of inhibitory postsynaptic currents in cultured rat hippocampal neurones. J Physiol (Lond) 403:41-55.

Bekkers JM, Stevens CF (1989) NMDA and non-NMDA receptors are co-localized at individual excitatory synapses in cultured rat hippocampus. Nature 341:230-233.

Bekkers JM, Richerson GB, Stevens CF (1990) Origin of variability in quantal size in cultured hippocampal neurons and hippocampal slices. Proc Natl Acad Sci USA 87:5359-5362.

Bormann J, Hamil OP, Sakmann B (1987) Mechanism of anion permeation through channels gated by glycine and $\gamma$-aminobutyric acid in mouse cultured spinal neurones. J Physiol (Lond) 385:243-286.

Buckley K, Kelly RB (1985) Identification of a transmembrane glycoprotein specific for secretory vesicles of neuronal and endocrine cells. J Cell Biol 100:1284-1294.

Capecchi MR (1989) Altering the genome by homologous recombination. Science $244: 1288-1292$.

Cepko C (1988) Immortalization of neural cells via oncogene transduction. Trends Neurosci 11:6-8.

Craig AM, Banker G (1994) Neuronal polarity. Annu Rev Neurosci $17: 267-310$

Dinsmore JH, Solomon F (1991) Inhibition of MAP2 expression affects both morphological and cell division phenotypes of neuronal differentiation. Cell 64:817-826.

Edwards FA, Konnerth A, Sakmann B (1990) Quantal analysis of inhibitory synaptic transmission in the dentate gyrus of rat hippocampal slices: a patch-clamp study. J Physiol (Lond) 430:213-249.

Fischbach GD, Nelson PG (1977) Cell culture in neurobiology. In: Handbook of physiology, Scct 1, The nervous system (Kandel ER, ed), pp 719-774. Bethesda: American Physiological Society.

Fishell G (1995) Striatal precursors adopt cortical identities in response to local cues. Development 121:803-812.

Fletcher TL, Cameron P, De Camilli P, Banker G (1991) The distribution of synapsin 1 and synaptophysin in hippocampal ncurons dcvcloping in culture. J Neurosci 11:1617-1626.

Forsythe ID, Westbrook GL (1988) Slow excitatory postsynaptic currents mediated by $N$-methyl-D-aspartate receptors on cultured mouse central neurones. J Physiol (Lond) 396:515-533.

Gage FH, Ray J, Fisher LJ (1995) Isolation, characterization, and use of stem cells from the CNS. Annu Rev Neurosci 18:159-192.

Galileo DS, Gray GE, Owens GC, Majors J, Sanes JR (1990) Neurons and glia arise from a common progenitor in chick optic tectum: demonstration with two retroviruses and cell type-specific antibodies. Proc Natl Acad Sci USA 87:458-462.

Goslin K, Schreyer DJ, Skene JHP, Banker G (1990) Changes in the distribution of GAP-43 during the development of neuronal polarity. J Neurosci 10:588-602.

Hales TG, Tyndale RF (1994) Few cell lines with GABA ARNA have functional receptors. J Neurosci 14:5429-5436.

Hestrin S (1992) Activation and desensitization of glutamate-activated channels mediating fast excitatory synaptic currents in the visual cortex. Neuron 9:991-999.
Hestrin S, Nicoll RA, Perkel DJ, Sah P (1990) Analysis of excitatory synaptic action in pyramidal cells using whole-cell recording from rat hippocampal slices. J Physiol (Lond) 422:203-225.

Huettner JE, Baughman RW (1986) Primary culture of identified neurons from the visual cortex of postnatal rats. J Neurosci 6:3044-3060.

Huettner JE, Baughman RW (1988) The pharmacology of synapses formed by identified corticocollicular neurons in primary cultures of rat visual cortex. J Neurosci 8:160-175.

Jahn R, Schiebler W, Ouimet C, Greengard P (1985) A 38,000-dalton membrane protein (p38) present in synaptic vesicles. Proc Natl Acad Sci USA 82:4137-4141.

Jonas P, Major G, Sakmann B (1993) Quantal components of unitary EPSCs at the mossy fibre synapse on CA3 pyramidal cells of rat hippocampus. J Physiol (Lond) 472:615-663.

Jones-Villeneuve FMV, McBurney MW, Rogers KA, Kalnins VI (1982) Retinoic acid induces embryonal carcinoma cells to differentiate into neurons and glial cells. J Cell Biol 94:253-262.

Jones-Villeneuve EMV, Rudnicki MA, I Iarris JГ, McBurney MW (1983) Retinoic acid-induced neural differentiation of embryonal carcinoma cells. Mol Cell Biol 3:2271-2279.

Kleppner SR, Robinson KA, Trojanowski JQ, Lee VM-Y (1995) Transplanted human neurons derived from a teratocarcinoma cell line (NTera-2) mature, integrate, and survive for over 1 year in the nude mouse brain. J Comp Neurol 357:618-632.

Krupp J, Feltz P (1993) Synaptic- and agonist-induced chloride currents in neonatal rat sympathetic preganglionic neurones. J Physiol (Lond) 471:729-748.

Liao D, Hessler NA, Malinow R (1995) Activation of postsynaptically silent synapses during pairing-induced LTP in CA1 region of hippocampal slice. Nature 375:400-404.

Liu G, Tsien RW (1995) Properties of synaptic transmission at single hippocampal synaptic boutons. Nature 375:404-408.

LoPresti P, Poluha W, Poluha DK, Drinkwater E, Ross AH (1992) Neuronal differentiation triggered by blocking cell proliferation. Cell Growth Differ 3:627-635.

Magnuson DSK, Morassutti DJ, Staines WA, McBurney MW, Marshall KC (1995) In vivo electrophysiological maturation of neurons derived from a multipotent precursor (embryonal carcinoma) cell line. Dev Brain Res 84:130-141

McBurney MW, Reuhl KR, Ally AI, Nasipuri S, Bell JC, Craig J (1988) Differentiation and maturation of embryonal carcinoma-derived neurons in cell culture. J Neurosci 8:1063-1073.

Meiri KF, Pfenninger KH, Willard MB (1986) Growth-associated protein, GAP-43, a polypeptide that is induced when neurons extend axons, is a component of growth cones and corresponds to pp46, a major polypeptide of a subcellular fraction enriched in growth cones. Proc Natl Acad Sci USA 83:3537-3541.

Meiri KF, Willard M, Johnson MI (1988) Distribution and phosphorylation of the growth-associated protein GAP-43 in regenerating sympathetic neurons in culture. J Neurosci 8:2571-2581.

Mennerick S, Que J, Benz A, Zorumski CF (1995) Passive and synaptic properties of hippocampal neurons grown in microcultures and mass cultures. J Neurophysiol 73:320-332.

Nelson PG (1976) Central nervous system synapses in cell culture. Cold Spring Harb Symp Quant Biol 40:359-371.

Nelson PG, Christian C, Nirenberg M (1976) Synapse formation between clonal neuroblastoma $X$ glioma hybrid cells and striated muscle cells. Proc Natl Acad Sci USA 73:123-127.

Nirenberg M, Wilson SP, Higashida H, Rotter A, Kreuger K, Busis N, Ray R, Kenimer J, Adler M, Fukui H (1983) Synapse formation by neuroblastoma hybrid cells. Cold Spring Harb Symp Quant Biol 48:70)7-715.

Nowak L, Bregestovski P, Ascher P, Herbet A, Prochiantz A (1984) Magnesium gates glutamate-activated channels in mouse central neurones. Nature 307:462-465.

Pleasure SJ, Page C, Lee VM-Y (1992) Pure, postmitotic, polarized human neurons derived from NTera 2 cells provide a system for expressing exngennus proteins in terminally differentiated neurons. J Neurosci 12:1802-1815.

Price J, Turner D, Cepko C (1987) Lineage analysis in the vertebrate nervous systcm by retrovirus-mediated gene transfer. Proc Natl Acad Sci USA 84:156-160.

Renfranz PJ, Cunningham MG, McKay RDG (1991) Region-specific differentiation of the hippocampal stem cell line HiB5 upon implantation into the developing mammalian brain. Cell 66:713-729. 
Ryder EF, Snyder EY, Cepko CL (1990) Establishment and characterization of multipotent neural cell lines using retrovirus vector-mediated oncogene transfer. J Neurobiol 21:356-375.

Schubert D, Heinemann S, Carlisle W, Tarikas H, Kimes B, Patrick J, Steinbach JH, Culp W, Brandt BL (1974) Clonal cell lines from the rat central nervous system. Nature 249:224-227.

Schubert D, Heinemann S, Kidokoro Y (1977) Cholinergic metabolism and synapse formation by a rat nerve cell line. Proc Natl Acad Sci USA $74: 2579-2583$

Segal MM, Furshpan EJ (1990) Epileptiform activity in microcultures containing small numbers of hippocampal neurons. J Neurophysiol 64:1390-1399.

Shirasaki T, Klee MR, Nakaye T, Akaike N (1991) Differential blockade of bicuculline and strychnine on GABA- and glycine-induced responses in dissociated rat hippocampal pyramidal cells. Brain Res 561:77-83.

Skene JHP, Willard M (1981) Axonally transported proteins associated with axon growth in rabbit central and peripheral nervous systems. J Cell Biol 89:96-103.

Sloboda RD, Rudolph SA, Rosenbaum JL, Greengard P (1975) Cyclic AMP-dependent endogenous phosphorylation of a microtubialassociated protcin. Proc Natl Acad Sci USA 72:177-181.

Snyder EY, Deitcher DL, Walsh C, Arnold-Aldea S, Hartwieg EA, Cepko CL (1992) Multiple neural cell lines can engraft and participate in development of mouse cerebellum. Cell 68:33-51.

Sommer B, Köhler M, Sprengel R, Seeburg PH (1991) RNA editing in brain controls a determinant of ion flow in glutamate-gated channels. Cell 67:11-19.

Staines WA, Morassutti DJ, Reuhl KR, Ally AI, McBurney MW (1994) Neurons derived from P19 embryonal carcinoma cells have varied morphologies and neurotransmitters. Neuroscience 58:735-751.

Sucher NJ, Brose N, Deitcher DL, Awobuluyi M, Gasic GP, Bading H, Cepko CL, Greenberg ME, Jahn R, Heinemann SF, Lipton SA (1993)
Expression of endogenous NMDAR1 transcripts without receptor protein suggests post-transcriptional control in $\mathrm{PC} 12$ cells. J Biol Chem 268:22299-22304

Südhof TC, Czernik AJ, Kao H-T, Taki K, Johnston P $\Lambda$, Horiuchi $\Lambda$, Kanazir SD, Wagner MA, Perin MS, De Camilli P, Greengard P (1989) Synapsins: mosaics of shared and individual domains in a family of synaptic vesicle phosphoproteins. Science 245:1474-1480.

Takahashi T, Momiyama A, Hirai K, Hishinuma F, Akagi H (1992) Functional correlation of fetal and adult forms of glycine receptors with developmental changes in inhibitory synaptic receptor channels. Neuron 9:1155-1161.

Temple S (1989) Division and differentiation of isolated CNS blast cells in microculture. Nature 340:471-473.

Tong G, Jahr CE (1994) Block of glutamate transporters potentiates postsynaptic excitation. Neuron 13:1195-1203.

Turetsky DM, Huettner JE, Gottlieb DI, Goldberg MP, Choi DW (1993) Glutamate receptor-mediated currents and toxicity in embryonal carcinoma cells. J Neurobiol 24:1157-1169.

Turner D, Cepko C (1987) Cell lineage in the rat retina: a common progenitor for neurons and glia persists late in development. Nature 328:131-136.

Weisskopf MG, Nicoll RA (1995) Presynaptic changes during mossy fibre LTP revealed by NMDA receptor-mediated synaptic responses. Nature 376:256-259.

Wiedenmann B, Franke WW (1985) Identification and localization of synaptophysin, an integral membrane glycoprotein of $M_{\mathrm{r}} 38,000$ characteristic of presynaptic vesicles. Cell 41:1017-1028.

Younkin DP, Tang C-M, Hardy M, Reddy UR, Shi Q-Y, Pleasure SJ, Lee VM-Y, Pleasure D (1993) Inducible expression of neuronal glutamate receptor channels in the NT2 human cell line. Proc Natl Acad Sci USA 90:2174-2178. 